\title{
Computational Thinking in K-12: An analysis with Mathematics Teachers
}

\author{
Janice Teresinha Reichert ${ }^{1 *}$, Dante Augusto Couto Barone ${ }^{2}$, Milton Kist ${ }^{1}$ \\ ${ }^{1}$ Federal University of the Fronteira Sul - UFFS, BRAZIL \\ 2 Federal University of Rio Grande do Sul - UFRGS, BRAZIL
}

Received 27 January $2020 \cdot$ Accepted 9 March 2020

\begin{abstract}
The article highlights and discusses aspects about the initial perceptions of Computational Thinking of a group of Mathematics teachers in K-12, estimates the contributions of a continuing education course on the subject and addresses possible changes in the participants' way of teaching. The case study was conducted through continuing education course and focused on the application of questionnaires with open and closed questions, as well as reports on the inclusion of activities, by the participants, in their teaching practice. The answers were analyzed from a qualitative perspective and the results obtained point to an initial lack of knowledge of the participants about the subject, especially in their relations with the field of mathematics. The offering of the course led to a significant learning on the subject, development of methodologies for the introduction of Computational Thinking in mathematics classes and reflections on how to teach and learn.
\end{abstract}

Keywords: Brazil's common national base curriculum, K-12, continuing education, computational thinking

\section{INTRODUCTION}

In 2006, National Science Foundation's (NSF) director of computational research, Jeanette Wing popularized the term "Computational Thinking" through an article called "Computational Thinking", arguing that the way Computer Scientists think about the world is useful in other contexts, thus starting a discussion about their role in all fields of knowledge.

However, some ideas spread by Wing were already present in Papert's works. In the article "Twenty things to do with a computer" (Papert \& Solomon, 1971), one can see that the ideas of Computational Thinking already existed but were not named with that term. In the year 1980, Papert in his book entitled "Mindstorms: Children, Computers and Powerful Ideas" (Papert, 1980), used the term "Computational Thinking" in the literature.

The adoption of Computational Thinking (CT) ideas and programming teaching in K-12 schools can be found in national and international programs and initiatives (Barr \& Stephenson, 2011; Guzdial, 2008; Haseski, Ilic \& Tugtekin, 2018; Kong \& Abelson, 2019; Royal Society, 2012).
In December 2018 in Brazil, the new Common National Base Curriculum (BNCC) (BRASIL, 2018) for Elementary and High School Education was approved, which is "a normative document that defines the organic and progressive set of essential learnings that all students must develop throughout the stages and modalities of K-12" (BRASIL, 2018, p. 7).

Computational Thinking (CT) is present at BNCC. More specifically, in the Elementary School stage, the term is associated with the specific competence and "Algebra" thematic unit of the Mathematics area, which states that learning Algebra, Numbers, Geometry and Probability and Statistics can contribute to the development of Computational Thinking of students (BRASIL, 2018, p. 271).

According to Barcelos and Silveira (2012) a strategy for insertion of the CT in Basic Education must occur through pre-existing subjects in the curriculum, such as Mathematics. Similarly, Barr and Stephenson (2011) describe a list of suggestions for the insertion of CT in the subjects of Mathematics, Science, Social Studies, Languages and Arts. According to these authors, students should start working on problem solving using 


\section{Contribution to the literature}

- In addition to emphasizing the lack of knowledge of K-12 Mathematics teachers on the subject of Computational Thinking, especially when referring to integration in the discipline, the study highlights the need for a direct follow-up to teachers so that the theme is included in K-12 education.

- The study presents way of introducing the CT in the discipline of Mathematics and, at the same time, discusses the challenges resulting from this inclusion. In Brazil, this study is a pioneer in the area.

- The research also highlights the need for a Computer Science professional to monitor the activities in the schools, especially in the area of educational robotics and programming. The form of this professional's collaboration in the activities, as presented in this study, is fundamental and we are not aware of any works in this sense.

- The characteristics presented during the research for the inclusion of CT in K-12 Education in existing curricular subjects, although related to a group of teachers in the area of Mathematics, can be extended to other groups and other areas of knowledge.

algorithmic and computational methods and tools in Elementary and High School.

Considering the current propositions regarding the inclusion of CT in K-12, it is necessary to investigate teaching methodologies of CT associated with Mathematics, which can be incorporated into the teacher's practice in the classroom. Thus, this article presents a description and analysis of activities carried out during a continuing education course with in-service mathematics teachers who work in the final years of elementary school of the municipal education system in the state of Santa Catarina - Brazil, always emphasizing that the teaching process means that the teachers must seek to meet the knowledge they already have in order to help them with the new knowledge.

It is believed that a training course should provide participants with feelings of comfort to learn and develop a "reflective posture to constantly review their own practice, as well as criticality and autonomy to relativize their intentions at certain moments of the interaction" (Prado \& Martins, 2005, p. 2).

\section{COMPUTATIONAL THINKING AND MATHEMATICS TEACHING IN K-12}

In his book Mindstorms: Children, Computers, and Powerful Ideas, Papert (1980) discusses the impact of the computer on learning, in which it is the tool that gives children the conditions to get in touch with Science, Mathematics, and modeling. For the author, "programming means nothing more or less than communicating to the computer in a language that it and the human user can both understand" (Papert, 1980, p. 18). It is noticeable, in this sentence, the presence of themes related to what today is called Computational Thinking (CT), however, there is no concern of the author in defining the concept. The term "Computational Thinking" is mentioned once, referring to the integration of CT in everyday life, however, in that period there was no mobilization for the diffusion of its characteristics.
Authors such as Wing (2006), Wing (2014), Royal Society (2012) and ISTE/CSTA (2011) present different definitions for the term Computational Thinking. A common feature among the definitions is that all of them mention problem solving based on the fundamental concepts of Computer Science.

In this sense, Kalelioglu, Gülbahar and Kukul, (2016) and Valente (2019) emphasize that there is no accepted or well-known definition of CT that has been scientifically proven, as several researchers seem to perceive the concept in a slightly different way and finding a definition that every researcher agrees has been a difficult task.

Haseski et al. (2018) conducted a database search process in publications up to 2016, totaling 59 definitions, of which 38 were from 2011 to 2016. The analysis of this study has showed that the definition of CT uses several concepts, and resolution of problems appears 121 times; technology 53 times; thought 35; personal characteristics 16 times; operational characteristics 12; quality 10 and social characteristics 9 times.

We agree with Barr and Stephenson (2011) that, to be useful, a definition must demonstrate in what ways the CT can be incorporated into the classroom, as it will make its use more accessible by the teacher and ease its integration in different subjects. Thus, it is believed that the definition that corroborates with the assumptions of this work is:

an approach to solving problems in a way that can be implemented with a computer: students become not merely tool users but tool builders. They use a set of concepts, such as abstraction, recursion, and iteration, to process and analyze data, and to create real and virtual artifacts. (Barr \& Stephenson, 2011, p. 51, authors' emphasis).

Regarding the inclusion of the CT in Brazil's K-12, the Common National Base Curriculum (BNCC) rules, in the Elementary School stage, does not establish the obligation of a specific curriculum component of the area 
of Computer Science. However, in the initial text of Mathematics, regarding the skills and abilities, the presence of the CT is observed:

Mathematical problem-solving, research, project development and modeling processes can be cited as privileged forms of mathematical activity, which is why they are both an object and strategy for learning throughout elementary school. These learning processes are potentially rich for the development of fundamental competences for mathematical literacy (reasoning, representation, communication and argumentation) and for the development of computational thinking (BRASIL, 2018, p. 266).

In the sixth specific competence in Mathematics, characteristics of CT can be found:

Facing problem-situations in multiple contexts, including imagined situations, not directly related to the practical-utilitarian aspect, expressing their answers and synthesizing conclusions, using different registers and languages (graphs, tables, diagrams, as well as text written in the mother language and other languages to describe algorithms, such as flowcharts, and data) (BRASIL, 2018, p. 267).

Subsequently, CT is mentioned when referring to the learning of Algebra as well as those learnings related to other fields of Mathematics (numbers, geometry and probability and statistics), can contribute to its development, highlighting the importance of algorithms and flowcharts in Mathematics classes (BRASIL, 2018).

Research led by Code.Org (2016), Liukas (2015) and BBC Learning (2015) feature four characteristics or "pillars" for the CT, namely: Decomposition, Pattern Recognition, Abstraction and Algorithms. In this sense, the text of the Common National Base Curriculum (BNCC) exposes the relationship between Algebra and the CT pillars, "another ability related to Algebra that is closely related to computational thinking is the identification of patterns for establishing generalizations, properties and algorithms" (BRASIL, 2018, p. 271, authors' emphasis).

The pillars of CT can also be observed in the BNCC which refers that the algorithmic language has commonalities with the algebraic language (BRASIL, 2018).

In the presentation of the essential learnings from elementary to high school, there is another reference to CT,

"the area of Mathematics in elementary school focuses on the understanding of concepts and procedures in their different fields and the development of computational thinking, aiming at solving and formulating problems in different contexts" (BRASIL, 2018, p.471, authors' emphasis).

According to the previous propositions it is important to analyze CT from the perspective of Mathematics teaching. Valente (2016) highlights that the introduction of CT is a great challenge, and it is difficult to determine how to approach the subject in education and, therefore, how to train educators in the subject. Even so, different initiatives have been carried out.

Rocha and Prado (2014) have presented an analysis of an experience carried out in a Mathematics teachers' continuing education course, with a 30-hour workload, which aimed to provide the teacher with greater autonomy in the use of technological resources in schools with the contents of Mathematics. This experience has showed that the elaboration of a pedagogical activity with the use of programming for the creation of educational software's favors the reflection of the teacher about his practice.

Holmes, Prieto-Rodriguez, Hickmott and Berger (2018) report on the experience of CT integration in teaching Mathematics in classrooms in New South Wales, Australia. The pilot project ran for 8 weeks, beginning with a 2-day professional development workshop and ending with the final socialization, in which teachers shared their experiences and samples of students' works. The authors have observed changes in teachers' perceptions of their ability to teach Mathematics with programming.

On the other hand, Barros, Reategui, Meira and Teixeira (2018) describe the implementation of a teacher training program on concepts related to CT using Scratch as an implementation tool, detecting some resistance of teachers of Mathematics to accept the CT as a classroom tool.

Despite the considerable differences in the adherence of Mathematics teachers to the implementation of the Computational Thinking in the classroom, in previous studies, no identification of any predominant contextual factor (e.g. teacher's experience or level of education) that could explain such differences was evidenced.

Furthermore, despite previous considerations, there is a lack of studies relating CT with Mathematics in teacher training experiences. Barcelos, Muñoz, Villarroel and Silveira (2018), in a systematic literature review of works that present didactical activities developing the CT and Mathematics competences, skills or content, including studies published between 2006 to 2015, only found five papers, in a universe of 59 , related to teacher training. The authors also conclude that it is possible to identify advances in the availability and variety of didactic activities involving CT and Mathematics, however, there are still target audiences and mathematical skills that have been little explored by the community. 
The results of the work of Barcelos et al. (2018) corroborate the analysis presented by Yadav, Stephenson and Hong (2017), as they point out that little has been done to examine the instructional, curricular and pedagogical implications related to teacher's initial and continuing education related to the inclusion of $\mathrm{CT}$ in basic education.

Considering the period from 2016 to 2019, despite the significant increase in publications related to the inclusion of CT in K-12, from the literature analysis, the predominance of works from the perspective of experience involving students can still be noted. In this sense, the importance of addressing the subject of CT with in-service Mathematics teachers in basic education is highlighted, with the aim of investigating teaching methodologies of the CT associated with Mathematics and analyzing possible obstacles to its implementation in the classroom.

Regarding the learning theory used and encouraged during the course, Constructionism stands out. According to Papert (1993) it is necessary to look at the individual as a being that not only develops by external stimuli but has the ability to observe and interpret the way to create his own knowledge.

Papert's Constructionism is a reconfiguration of ideas which were already created and defended by Piaget (1976), known as constructivist ideas, in which children are thinking beings and are able to build their own cognitive structures, even without being taught. However, at that time, there was little research on this subject which led him to find ways to create conditions for the student to learn as much as possible, with the least teaching interference. Valuing the mental construction of the individuals, supported by their own world constructions.

Constructionism, as proposed by Papert, denies the belief that the path to better learning must be the improvement of instruction, which the author names as instructionism, and adds that "the goal is to teach in order to produce more learning from the bare minimum of teaching" (Papert, 1993, p. 134).

In 1993 Papert uses the proverb: "If a man is hungry, you can give him a fish, but it is better to give him a rod and teach him how to fish" (p. 134) to emphasize that it is necessary to give the learner the best conditions so that he himself, under these conditions, can create and abstract his own knowledge.

Following this line of reasoning, the Constructionist approach was used in this continuing education course to encourage the teacher to build his knowledge about the use of technological resources applied to mathematics teaching. The reflection on the teaching practice was present during the course and a change of posture, leaving an instructional teaching style, could be noticed in the reports of the didactic sequences applied by the teachers.

\section{METHODOLOGY}

The descriptive field research through the case study was performed with theoretical and experimental parts. The experiment took place during a continuing education course, taught by the authors themselves, with eight face-to-face meetings, from April to November 2019, lasting 32 hours, offered at the computer lab of the Federal University of Fronteira Sul.

The course covered introductory concepts of Computational Thinking, unplugged activities (without computer use), Scratch ${ }^{1}$ programming, presentation of basic robotics concepts and block based programming using ArduBlock ${ }^{2}$, as well as electronic components and other materials needed for robotics learning, such as: Arduino Uno Boards, LED'S, Jumpers, motors, heat sensors, infrared, Protoboard, among others.

Twenty-eight Mathematics teachers aged 23 to 60 years old, with K-12 teaching experience varying from 30 days to 32 years, members of a municipal public education system, participated in the activity.

The nature of this study did not allow the random selection of the sample and no control group was used as it is a continuing education course, for this reason, this research is characterized as a quasi-experimental study. According to Shadish, Cook and Campbell (2001), quasiexperiments are studies that do not have a random distribution of subjects by treatments or a control group. They are studies with intact groups, groups that were already formed before the experiment. The researcher uses alternative methods to the group for control and validation of the study.

The investigation has adopted a qualitative design, and data collection happened through observation, logbook records, recordings and photographs. Questionnaires with essay and objective questions were applied to the participants before and after the intervention, which made it possible to gather data related to previous knowledge and conceptions about the subject, comparing their evolution and analyzing aspects about the knowledge acquired during the course.

An important moment of data collection occurred during the reporting of the didactic sequences applied in the schools, held at the last meeting.

The data collected in this study aimed to answer the following questions:

- What initial perceptions does the teacher group have about CT and its way of classroom integration?

- What are the possible contributions of the continuing education course?

- After the development of the course, is it possible to observe a change in the attitudes of participants from an instructional-based teaching to a constructivist teaching? 
Table 1. Activities Description

\begin{tabular}{|c|c|c|c|}
\hline Class number & Content & Activities Description & Duration \\
\hline 01 & $\begin{array}{l}\text { Computational thinking and its use in } \\
\text { everyday situations. }\end{array}$ & $\begin{array}{l}\text { Main concepts of Computational Thinking. BNCC assumptions } \\
\text { regarding Computational Thinking. Research and publications } \\
\text { related to the subject. }\end{array}$ & 4 hours \\
\hline 02 & $\begin{array}{l}\text { Use of unplugged computing for the } \\
\text { development of Computational Thinking. }\end{array}$ & $\begin{array}{l}\text { Computational Thinking with unplugged activities. Activities } \\
\text { relating CT pillars and Mathematics content. }\end{array}$ & 4 hours \\
\hline 03 & Scratch & $\begin{array}{l}\text { Using the Scratch programming language to approach } \\
\text { Mathematics contents. }\end{array}$ & 4 hours \\
\hline 04 & Basic electronics & $\begin{array}{l}\text { Introduction to robotics: Arduino Uno board, use of protoboard, } \\
\text { sensors, Led resistors and basic tools. Arduino installation. First } \\
\text { programs in Arduino. Basic electronics and connections between } \\
\text { Arduino board and computer. Using Arduino programming to } \\
\text { transfer commands to the board. }\end{array}$ & 4 hours \\
\hline 05 & Educational robotics & $\begin{array}{l}\text { Educational robotics: motors and drives, sensors. Basic Project } \\
\text { with Arduino. }\end{array}$ & 4 hours \\
\hline 06 & $\begin{array}{l}\text { Unplugged activities, Scratch and } \\
\text { educational robotics. }\end{array}$ & $\begin{array}{l}\text { Individual groups orientations for the elaboration of the didactic } \\
\text { sequences. Definition of the approach being used (unplugged, } \\
\text { Scratch, or educational robotics) and the Mathematical subject to } \\
\text { be developed. }\end{array}$ & 4 hours \\
\hline 07 & $\begin{array}{l}\text { Unplugged activities, Scratch and } \\
\text { educational robotics. }\end{array}$ & $\begin{array}{l}\text { Individual group orientations for the execution of classroom } \\
\text { didactic sequences. }\end{array}$ & 4 hours \\
\hline 08 & $\begin{array}{l}\text { Unplugged activities, Scratch and } \\
\text { educational robotics. }\end{array}$ & $\begin{array}{l}\text { Socialization reports on the implementation of didactic } \\
\text { sequences in schools. Application of the final questionnaire. }\end{array}$ & 4 hours \\
\hline
\end{tabular}

\section{Activity Development}

In the continuing education course, the concepts of CT were related to the contents of Mathematics through a participatory method, in which moments of reflection have prevailed, as teachers could express their expectations and anxieties.

The didactic material ${ }^{3}$ used during the course was developed for a better follow-up by the participants. The schedule of activities is described in Table 1.

After the 5th meeting, six working groups were set up to effectively implement the activities at the schools. Each group was responsible for the elaboration and application to the students of K-12 stage, of a didactic sequence, using one or more of the methodologies approached during the course and associated to the content of the Mathematics subjects from the 6th to the 9th grade. During this period the teachers were guided by the researchers in the elaboration and execution of the activities. The reporting on the application of the didactic sequence happened at the last meeting.

\section{RESULTS AND DISCUSSIONS}

\section{Initial CT Insights}

The initial questionnaire consisted of nine questions, most of them open-ended, four of them related to general characteristics of the teachers (initial training, knowledge of programming languages, acting time in K12 and possible postgraduate training), and five about CT conceptions and its inclusion in K-12.

Regarding the background of the participants, all of them have a degree in Mathematics and only three do not have a postgraduate course, and there are teachers with less than 5 years of experience in K-12 contrasting with teachers with up to 32 years of experience. Regarding knowledge of programming languages, only one of the participants answered in the affirmative.

Following, the questions related to the conceptions of CT and its inclusion in K-12 are presented.

Question 1: What do you think about introducing computer science concepts (e.g. robotics, programming) into Math classes? Are you on favor or contrary? Why? In this case, $100 \%$ of participants answered that they are favorable to its use in the classroom. On the reasons, the answers emphasize the use of technology in the classroom and the adoption of different methodologies.

These results are also present in other countries. Peralta and Costa (2007), following a study in Spain, Greece, Italy and Portugal, concluded that, in general, teachers from these countries show a positive attitude towards technologies and are aware of their potential to respond to social and educational challenges of the present and future ones.

Question 2: Do you use technology resources (computer, projector, digital whiteboard, video lesson, etc) in the classroom? If yes, which? Figure 1 shows the answers, 


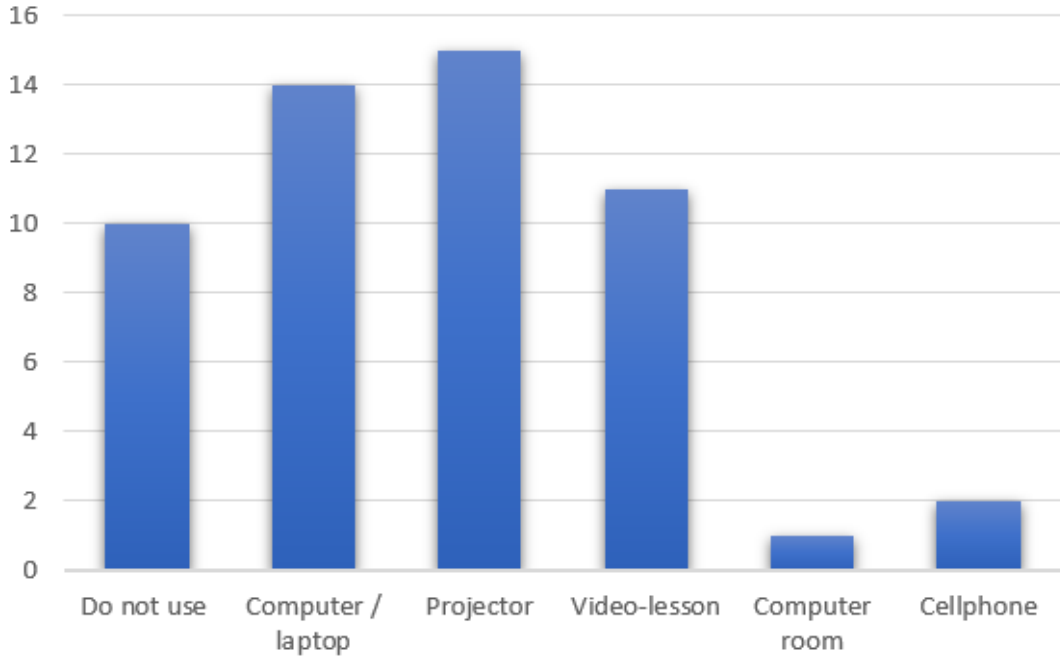

Figure 1. Technology Resources most used by participants

These answers show that ten teachers do not use any resources in their classes. The most used technological resource is the projector, and only one teacher says that he uses the computer room. According to Viera (2015), there is an underuse of equipment in most schools because teachers do not know how to use them as teaching tools.

From a multiple case study on the competence and confidence of K-12 teachers on the use of technology in educational practices, conducted in five European countries (Spain, Greece, the Netherlands, Italy and Portugal), Peralta and Costa (2007) point out that technologies play a secondary role in teachers' practices and are only used as a complement to other materials. Teachers know how to use the computer, but not in the classroom with their students, and those who use it have not significantly changed attitudes, roles, and ways of teaching and learning. Practices are not pedagogically consistent with the principles of the constructivist learning method and technologies play a secondary role.

These results are also observed in other countries, Mailizar e Fan (2020) in a quantitative study with 341 high school Mathematics teachers in Indonesia, with the aim of investigating the teachers' knowledge about Information and Communication Technology (ICT) and its use has concluded that most of them have inadequate knowledge of ICT and knowledge of ICT use in teaching.

Question 3: Have you ever read or heard about "Computational Thinking"? Only 7\% of teachers say they have knowledge of the subject, $24 \%$ said they had no knowledge of it and $69 \%$ had heard or read about it, but are not clear about what $\mathrm{CT}$ is. The results corroborate the work of Pasqual Júnior and De Oliveira (2019) which during an eight-hour workshop, with the participation of 25 teachers from an inland city of Rio Grande do Sul - Brazil, in a similar question, the answer was that $100 \%$ of participants said they did not know anything about the subject.
Question 4: Does the introduction of Computational Thinking depend on the use of computer programs? 52\% answered yes, while $48 \%$ disagreed. Most participants are unaware of the "unplugged" activities that introduce CT pillars without the use of computers. The misconception about the principles of Computation and CT is not restricted to Mathematics teachers. PrietoRodrigues and Berreta (2014) conducted a survey with teachers participating in a Computing event. One of the goals was to investigate their understanding of Computer Science. The research results indicate a common misconception about the nature of Computer Science, relating it mainly to programming.

Question 5: How does Computational Thinking relate to other curricular components and fields? Please provide specific examples. In this question, 24 teachers said they did not know how to relate $\mathrm{CT}$ with any curricular component. Only four teachers presented answers, namely: With Geography through the use of GPS; in Agriculture it can assist in the analysis of production; through programs that are created to understand how to create a robot; in all areas of knowledge. Participants are unaware of the usability and characteristics of $\mathrm{CT}$, and there is as a lack of clarity in understanding that $\mathrm{CT}$ is more than just using computers and technology.

During the development of the activities, participants were concerned about the applicability, in schools, of the activities developed in the course, as noted in the reports: it is no use for us to take this course, because at school we do not have these resources available; I don't know if I can use this in my classes, as it involves many other concepts; I will need help using this in my classes; my classes are too big and hectic to do these activities with the whole class. One of the mentioned aspects refers to the lack of infrastructure and the other characterizes some resistance to introduce something completely new and apparently unknown. These records appear in previous studies, such as Curzon, Mcowan, Cutts and Bell (2009), which show resistance by teachers to adopt new methodologies. Still 
Table 2. Activities developed by the six groups

\begin{tabular}{clccc}
\hline Group & Content(s) addressed & \multicolumn{2}{c}{$\begin{array}{c}\text { School Methodology Number of classes the } \\
\text { year }\end{array}$} & $\begin{array}{r}\text { Numect was applied to } \\
\text { project }\end{array}$ \\
\hline 01 & Sine, cosine and tangent of an angle and Pythagora's Theorem & $9^{\text {th }}$ & Robotics & 01 \\
02 & Rule of three & $7^{\text {th }}, 8^{\text {th }}$ & Robotics & 02 \\
03 & First degree equations & $7^{\text {th }}, 8^{\text {th }}$ & Unplugged & 03 \\
04 & Area and perimeter of regular figures & $6^{\text {th }}$ & Scratch & 02 \\
05 & Geometry concepts (area, perimeter) & $7^{\text {th }}$ & Robotics \\
06 & Operations on natural numbers & $6^{\text {th }}, 7^{\text {th }}$, Unplugged & 01 \\
& System of first-degree equations & $8^{\text {th }}, 9^{\text {th }}$ & \\
\hline
\end{tabular}

according to these authors "many teachers are apprehensive about the use of teaching methods that involve students, for example, working in groups, solving problems or moving around the classroom" ( $p$. 97).

Due to the participants' concerns, in conversation with the management of the Municipal Secretary of Education to which the teachers are linked, a 20-hour intern, from the Computer Science Course of the Federal University of Fronteira Sul, was provided to assist teachers in robotics projects. The intern acted as an assistant in the classroom, keeping the teacher as the protagonist in the planning and implementation of the activities.

Still regarding the participants' records, there are concerns about the need to master a certain topic or tools. In this behavior a centralist view is observed, because the teachers are afraid of not completely mastering the content in order to clarify all of the students' doubts. Regarding this stance, (Papert, 1993, p.77) writes that "the main obstacle in the way for teachers to assume the role of learners is their inhibition in relation to learning". Other authors, such as Barros et al. (2018), also highlight the resistance of Mathematics teachers in regarding the use of computer science, showing that the process of acceptance of technology can be slow in relation to its advancement.

\section{Integration of Activities in Teaching Practice}

After the 5th meeting we suggested the development and application of a didactic sequence using the activities developed during the course, associating them with Mathematics contents from the 6th to the 9th grade. To do so, six groups were created and started having individualized orientations. At the beginning, each group was asked to determine the contents, school year and methodology chosen. Table 2 presents the details of the didactic sequences organized by the groups.

The groups that chose to use pedagogical robotics had the participation of the intern, who assisted the teacher in the execution of the activities. During this stage, some problems related to infrastructure were observed regarding computers and internet access.

The reporting of the experiences of the six groups, regarding the implementation of the didactic sequences in schools, took place at the last meeting. We believe this was one of the most important moments because the participants were able to express all the feelings and anxieties regarding the application of the didactic sequences. Following is a report on the activities developed during the application of the didactic sequences.

Group 1 used a laser attached to the robotic cart to work on trigonometry concepts: identifying length and height measurements, angle measurements and using the trigonometric relations of the right triangle, involving Sine, Cosine and Tangent. Only one teacher,

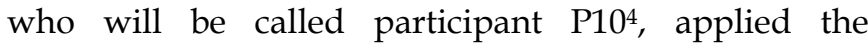
activities, but some students from another class attended to the activities.

In this sense, the speech of participant P11 stands out: my students went to watch classes at night and came back amazed, they wanted me to do it too, but I still do not feel confident to apply the activities. This same participant adds: Although I still do not feel prepared to introduce the activities in the classroom, I feel passionate about the activities using technologies and how this makes things easier for the teacher.

Participant P10 gets emotional reporting how the activities took place: it took us out of the comfort zone; It is very important not to create expectations in the students which cannot be fulfilled, because they feel inserted in the process and we cannot disappoint them, I became another teacher when performing these activities. Thus, it is clear how the continuing education course contributes to provoke reflections on classroom practice, corroborating Holmes et al. (2018) who, after an activity that lasted eight weeks, also observed changes in teachers' perceptions of their ability to teach Mathematics with programming.

Group 2 used robotics to, through the rule of three, calculate the distance traveled and relate time and speed to distance. Students had to perform the programming in all situations and compare it with the data collected during the practice. The activities were applied by two participants in different schools. The speech of participant P07 stands out: it was very gratifying, as it was the only time, I realized that the students made the calculations willingly. However, he adds: without the intern, it would have been impossible to develop robotics activities. This comment was ratified by the other participants. 
Through initial diagnosis we have detected that only one of the participants claimed to know some programming language, in this sense, the practice involving pedagogical robotics, which includes robot programming, is new and brings insecurity to the group. The works of Molina and Schlemmer (2011), Saito and Ribeiro (2013) and Nascimento (2015) point out, from the teachers' point of view, the possible causes of the resistance of using technologies in the school context, the lack of preparation and difficulty for its use.

Group 3 used unplugged activities to work with first degree equations. The application has occurred for a 7th grade class and two 8 th grade classes. For the 8th grade classes, participant P24 started the activities with a test to explore the familiar concepts of students about CT. After that, students had to describe the step by step to develop a routine activity, such as making a sandwich. After that, they did a "human robot" activity in which one student provided instructions and the other, blindfolded, should walk a circuit drawn on the floor. From this, the concept of algebraic equation was introduced, relating the number of steps that the robot must travel to move a certain pre-fixed distance. The activities were applied in two schools.

In the speech of participant P24, one can see how challenging and rewarding a less centralist approach can be: I realized that the planning can happen in a specific content, but other contents will show up in the course of the activity, and this is challenging. This same participant expresses his satisfaction in working with the activities: this approach will be incorporated into my teaching practice, for sure.

Participant teacher P03 performed the unplugged activities and invited the students to participate in an extracurricular project involving Scratch. In his words: I could not use Scratch with the whole class because it was a large class, besides, we had a lot of content to work with, which highlights the concern with the content and corroborates with Barros et al. (2018) when they highlight some resistance of teachers to accept the CT as a classroom tool. Also, Papert (1993, p. 73) in an analysis of the barriers to introducing the classroom computer as an instrument of change, writes: "many aspects of the school prevent teachers from working in the classroom as co-learners."

Group 4 used Scratch to draw regular flat figures and work on related concepts. The activity was applied by participant P06 in two classes of the same school. The activity was developed using the online version of the program. Regarding this, the participant P06 highlights: in some days of the activity when they were programming there was no internet or the internet crashed, and the students were disappointed.

Participant P06 also reports that students often come up with command questions that I had not explained yet. Given this speech, the researcher/trainer made an intervention asking the participant how she felt at this moment: I felt very good, the students helped me and helped each other, and adds, it was very nice because I noted that students who always had many difficulties were being extremely motivated.

In participant $\mathrm{P}^{\prime} \mathrm{6}^{\prime} \mathrm{s}$ speech, one can note characteristics of the constructionist teaching method, because the students acted as protagonists of their knowledge and became more independent, as they could help the teacher and colleagues. The guidance of the activities, although new to the teacher, did not bother him, on the contrary, made him feel rewarded by the students' motivation and interest in the subject.

In this sense, research by Sadovsky (2007), Oliveira (2009), Nacarato, Mengali and Passos (2011), Oliveira and Baraúna (2012) indicated that on the matter of Mathematics teaching, a pedagogical practice in which the expository transmission of contents prevails and the performance of exercises and activities that require from the student the ability of strictly repeating the information received verbally from the teacher is still prevalent in the school context.

International research highlights that the tendency to teach mathematics through more teacher-centred, is still a practice to be overcome, at all school levels. For example, there is evidence that some teachers, when given the opportunity of teaching Mathematics through problem solving to Israeli high school students (Leikin, Levav-Vineberg, Gurevich \& Mednikov, 2006), middle years New Zealand students (Ingram, Holmes, Linsell, Livy, McCormick \& Sullivan, 2019) and early years Australian students (Russo, Bobis, Downton, Hughes, Livy, McCormick \& Sullivan, 2019) have been initially reluctant to embrace more student-centred methodologies.

In the activities applied by Group 05, the students programmed a robotic cart with an attached brush to draw regular geometric figures on a checkered poster board. From this, they could explore concepts such as sides, angles, area and perimeter. The activities were applied in a 7th grade class by all members of the group. In participant P22's report: At first it was very scary, but I learned a lot. It requires a change in the teacher's attitude. Participant P12 adds: We had a hard time applying the activities, but students were always willing to help. I will study a little more to apply them by myself in my class. One can notice, again, reports regarding the difficulties related to specific knowledge of robotics, but also the change of attitude in their way of teaching.

Group 6 initially opted for Scratch, but after several attempts they had to give up and opt for the unplugged activities. This was due to the lack of adequate internet access to use the online version of the program and the impossibility of installing other versions. This group adapted the "sorting networks" activity, available in Bell, Witten and Fellows (2015), for a first-degree equation system and applied it in two classes of 8th and 
9 th grades. For the 6 th and 7 th grade students, the activity of building a maze with numbers from one to 20 was performed, so that for the character to be able to leave the maze the score of points should be 100 .

According to P19: in the beginning we were frustrated by not being able to do activities using computers, but during the development of activities, observing the involvement of students, we realized that even activities considered simple can be motivating and teacher P16 said: I believe the activities, even without the use of technology, have been useful to encourage students to learn the content and for that they are very important. The group's statements convey the initial idea of prioritizing computational resources over unplugged activities. However, the group itself realizes, after the intervention with the class, that the interest in a subject need not necessarily be related to the technology used, and that activities considered simple can also be motivating.

The use of unplugged activities with teachers in continuing education courses has also been studied by Curzon, Mcowan, Plant and Meagher (2014). The research took place through workshops, organized to explore the effectiveness of unplugged methods for introducing educators to the topics of Computing. The form-based assessment suggests that unplugged activities provide an inspiring and entertaining session for the teachers, which they find useful, interesting, and is said to enhance their self-confidence.

Despite the initial challenge and the difficulties reported, when asked by the researchers if they intended to continue the activities in schools, all teachers answered in the affirmative. It is worth highlighting an excerpt from Papert's work, which reflects the participants' feelings about the application of the activities: "teachers who give their students equal autonomy are thus stating their belief in a radically different theory of knowledge that requires much more effort from them and their students "(Papert, 2008, p. 70).

\section{Final Perceptions on Computational Thinking}

After the development of the activities, a final questionnaire with five questions was applied, three of them related to the continuing education course and perceptions about the inclusion of CT in the Mathematics subject and two questions about specific knowledge. A total of 24 participants answered the questions.

Question 1 (specific knowledge): Describe your definition of "Computational Thinking". The words used to describe its meaning were: "problem solving (10)", "logical reasoning (6)", " algorithm (4)", "skill (3)", "relate contents (1)". Some answers stand out: it is the thought process involving the formulation of a problem looking for its solution, whether a human or a computer can solve it; it is a way of formulating and solving problems efficiently, with or without the use of computers; using logical reasoning to solve problems."
The emphasis on problem solving corroborates the work of (Kalelioglu, Gülbahar \& Kukul, 2016) who, after analyzing qualitative content in $125 \mathrm{CT}$ articles, selected according to predefined criteria in six different databases and digital libraries, have determined,

Out of 125 articles analyzed, the words used to describe the meaning of the term CT are: problem solving $(22 \%)$, abstraction $(13 \%)$, computer $(13 \%)$, process $(9 \%)$, science $(7 \%)$, data $(7 \%)$, effective $(6 \%)$, algorithm $(6 \%)$, concepts $(5 \%)$, skill $(5 \%)$, tools $(4 \%)$ and analysis $(4 \%)$. (Kalelioglu et al., 2016, p. 589).

Authors such as (Bocconi, Chioccariello, Dettori, Ferrari \& Engelhardt, 2016; Yadav et al. 2011; Yadav, Mayfield, Zhou, Hambrusch, \& Korb, 2014), also consider that CT is based on problem solving. At the beginning of the course, $93 \%$ of participants stated that they were not aware, or were uncertain, about the subject.

We agree with Barr and Stephenson (2011) that, to be useful, a definition must show how the concept can be incorporated into the classroom. In this sense, $100 \%$ of the participants described CT according to one of the definitions presents in the literature, but which provides subsidies for their teaching practice. The answers show a greater understanding about the subject, making it fundamental for its use in an effective way.

Question 2 (specific knowledge): Name the main pillars of Computational Thinking. The answers are in Figure 2: 


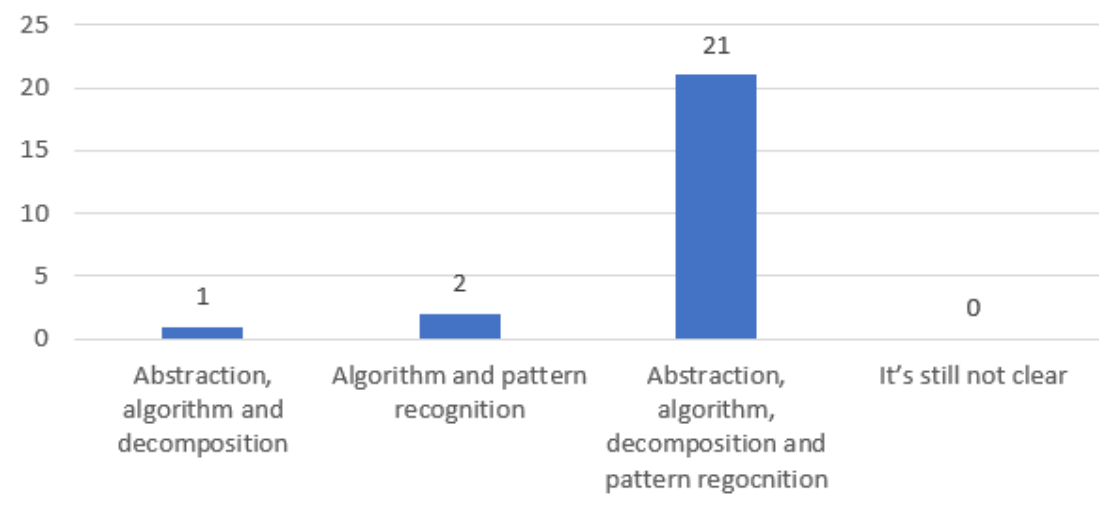

Figure 2. Main pillars of CT named by participants

Table 3. Question 4's questions and answers

\begin{tabular}{|c|c|c|c|c|c|}
\hline Question & $\begin{array}{l}\text { Strongly } \\
\text { disagree }\end{array}$ & Disagree & $\begin{array}{c}\text { Neither agree } \\
\text { nor disagree }\end{array}$ & Agree & $\begin{array}{l}\text { Completely } \\
\text { agree }\end{array}$ \\
\hline $\begin{array}{l}\text { Can unplugged activities without use of the computer be used in the } \\
\text { classroom, in the Mathematics subject? }\end{array}$ & $0.0 \%$ & $0.0 \%$ & $0.0 \%$ & $33 \%$ & $67 \%$ \\
\hline Can Scratch be used in the classroom, in the Mathematics subject? & $0.0 \%$ & $0.0 \%$ & $4 \%$ & $42 \%$ & $54 \%$ \\
\hline $\begin{array}{l}\text { Can activities involving programming and pedagogical robotics be } \\
\text { used in the classroom, in the Mathematics subject? }\end{array}$ & $0.0 \%$ & $8 \%$ & $17 \%$ & $46 \%$ & $29 \%$ \\
\hline $\begin{array}{l}\text { Have the meetings of this continuing education course contributed to } \\
\text { the teaching process in the Mathematics subject? }\end{array}$ & $0.0 \%$ & $0.0 \%$ & $8 \%$ & $50 \%$ & $42 \%$ \\
\hline $\begin{array}{l}\text { Is the availability of a computing professional, for the implementation } \\
\text { of unplugged activities at school, necessary? }\end{array}$ & $4 \%$ & $34 \%$ & $8 \%$ & $33 \%$ & $21 \%$ \\
\hline $\begin{array}{l}\text { Is the availability of a computing professional, for the implementation } \\
\text { of Scratch activities at school, necessary? }\end{array}$ & $0.0 \%$ & $13 \%$ & $25 \%$ & $33 \%$ & $29 \%$ \\
\hline $\begin{array}{l}\text { Is the availability of a computing professional, for the implementation } \\
\text { of pedagogical robotics activities at school, necessary? }\end{array}$ & $0.0 \%$ & $0.0 \%$ & $0.0 \%$ & $8 \%$ & $92 \%$ \\
\hline
\end{tabular}

There is no consensus on the characterization of the CT pillars, as an example we can mention the Brazilian Computer Society [SBC] (2017) which refers to three pillars: abstraction, analysis and automation, but most participants identify as main pillars those presented by Code.Org (2016), Liukas (2015) and BBC Learning (2015).

Question 3: Can CT development activities be integrated into the classroom? This was an objective question and $100 \%$ of participants marked the option: Yes, in curricular subjects, such as Mathematics for example. The other possible answers were: Yes, in a specific Computer subject and No. The answers show that participants were able to visualize, after participating in the continuing education course, the integration of the $\mathrm{CT}$ in the Mathematics subject.

In Question 4 the participants were asked to rate: a: (1) Strongly disagree, (2) Disagree, (3) Neither agree nor disagree, (4) Agree e (5) Completely agree, in each of the questions in Table 3.

From the participants' point of view, unplugged activities are more likely to be used in the classroom in comparison with other types of activities (Scratch and pedagogical robotics). Several factors can lead to this conclusion, such as the lack of infrastructure to apply activities involving technological resources, and also the lack of knowledge to apply activities involving Scratch or pedagogical robotics. In fact, the unplugged activities offer diverse possibilities and easiness to adapt to the
Mathematics contents, and are even more familiar to teachers, since in undergraduate courses there is usually the exploitation of playful methodological resources applied to teaching.

It is noticed that the participants agree that the continuing education course contributed to the teaching processes of the Mathematics subject. This can also be observed in the reports of the didactic sequences, in which we observed that there were considerations, by the participants, about the ways of teaching.

Regarding the computer professional, $100 \%$ of the participants considered it necessary for him to be present in activities involving pedagogical robotics. This feature can also be noticed in the reports of the didactic sequences.

According to the participants' perceptions, the need for the intern in Scratch and unplugged activities persists. This feature may mean some resistance or fear, from some participants, in the use of methodologies without the support of other professionals, because during the course development and application of activities in schools, no difficulties of knowledge were detected in the use of these approaches. However, during the continuing education course, the teachers had orientations from the researchers for the elaboration of the didactic sequences, and this gave them more confidence to apply the activities. 
Table 4. Difficulties reported by participants

\begin{tabular}{lc}
\hline Difficulty & Number of participants \\
\hline Robotics electronic components & 10 \\
Programming & 08 \\
Lack of general computer skills & 02 \\
Others & 02 \\
\hline
\end{tabular}

Question 5: Regarding the activities developed in this continuing education course, name your possible difficulties. Two participants stated that they had no difficulties. Table 4 presents the reported difficulties:

Difficulties regarding programming and knowledge related to educational robotics were reported by the participants throughout the course. It is noticeable that, in this work, the assistance of a Computing area intern was fundamental for the implementation of activities at the schools. He was responsible for organizing the computers, assisting in programming and handling electronic components, however, the teachers acted as main protagonists, as they prepared and conducted the activities. It should be noted that, in most schools participating in this research, there were no professionals with an exclusive workload for the computer lab.

According to the participants, another obstacle for the use of the tools presented during the course and the possible inclusion of the $\mathrm{CT}$ in Mathematics classes refers to the scarcity of infrastructure in the schools. In the work of Matos Filho, Da Silva and Queiroz (2008) these difficulties have already been pointed out and it seems that they still persist, even with the continuous technological advance. According to the authors, difficulties such as lack of maintenance due to its high cost, few trained teachers, no exclusive workload for laboratories, in addition to the natural resistance to changes, have served as obstacles to a greater insertion of information technology in K-12 stage education.

\section{CONCLUSION}

The objective of this work was to investigate pedagogical approaches of the CT associated with Mathematics, which can be incorporated into the teaching practice in the classroom. In this sense, three specific objectives were defined:

- Determine what initial perception a group of teachers have about CT and how it is integrated into the classroom;

- Estimate the possible contributions of the continuing education course;

- After the development of the course, observe possible changes in participants' attitude, moving from a traditional way of teaching, based on instruction, to teaching from a constructivist perspective.
Regarding perceptions, although $100 \%$ of the participants agreed with the introduction of computer science concepts (such as robotics and programming) in Mathematics classes in K-12, little knowledge was noticed on the subject, especially with regard to their inclusion in specific curricular components, with $93 \%$ of the participants saying that they did not know or were not clear about the subject.

Analyzing the contributions of the continuing education course, after the development of the activities, $100 \%$ of the participants were able to describe CT according to some definition present in the literature, with a predominance of $42 \%$ related to problem solving, corroborating the results presented by Kalelioglu et al. (2016) and Haseski et al. (2018).

The four pillars of CT were identified in the participants' responses and are consistent with the definitions presented by Code.Org (2016), Liukas (2015), BBC Learning (2015), Boucinha, Barone, Reichert, Brackmann and Schneider (2019) and Brackmann, Barone, Boucinha and Reichert (2019).

A certain difficulty was noted in the programming activities, which has led to changes in the initial schedule, such as the inclusion of an intern in the Computer Science area to monitor the activities in the schools. It is believed that the methodology used contributes to an effective inclusion of these activities in the teachers' practice.

During the participants' reports, reflections on the way of teaching and on the perception of how the student's learning process occurs, referring to the conception that knowledge cannot be readily and simply transmitted or transferred to another person. The teachers feel withdrawn from their comfort zone, as reported by participant P10, if confronted with more active students and participants, in which teaching no longer follows a linear trend, as unforeseen content may come up during the class.

According to previous propositions, it is believed that the objectives of this work have been achieved. Finally, it is worth highlighting the need to continue this work through the monitoring of the implementation of activities at the schools and permanent continuing education programs.

We agree with Valente (2019), as he highlights that studies on creating proposals and materials to collaborate with the implementation of digital technologies and media in education have a fundamental role so that the conceptions about CT can be disseminated in the educational scope. It is considered essential to develop supporting strategies, through research groups, educational institutions, government agencies etc., so that basic education teachers have confidence and feel supported in the implementation of activities. 


\section{Notes}

1Scratch's official website: https: / / scratch.mit.edu/

2Block programming language for Arduino: http:/ / blog.ardublock.com/

${ }^{3}$ Educational material used in the course:

https: / / drive.google.com/ open?id=1QxG9qK4koYe nb5eWPde7_gv5nQlwQhuO

4The teachers participating in the course were nominated from P01 to P28.

\section{REFERENCES}

Barcelos, T. S., \& Silveira, I. F. (2012). Pensamento Computacional e Educação Matemática: Relações para o Ensino de Computação na Educação Básica. XX Workshop sobre Educação em Computação (WEI), Curitiba, Paraná, Brasil.

Barcelos, T., Muñoz, R., Villarroel, R., \& Silveira, I. (2018). A Systematic Literature Review on Relationships Between Computational Thinking and Mathematics. Journal on Computational Thinking, 2(1), 23-35. https://doi.org/10.14210/ ijcthink.v2.n1.p23

Barros, T. T. T., Reategui, E. B., Meira, R. R., \& Teixeira, A. C. (2018). Avaliando a Formação de Professores no Contexto do Pensamento Computacional. Novas Tecnologias na Educação, 16(2), 556-565. https:/ / doi.org/10.22456/1679-1916.89274

Barr, V., \& Stephenson, C. (2011). Bringing computational thinking to K-12: what is Involved and what is the role of the computer science education community? Inroads, 2, 48-54. https:/ / doi.org/10.1145/1929887.1929905

BBC Learning. What is computational thinking? (2015). Retrieved on December 5, 2019 from http:/ / www. bbc.co.uk/education/guides/zp92mp3/revision

Bell, T., Witten, I. H., \& Fellows, M. (2015). CS Unplugged: An enrichment and extension programme for primaryaged students. Adapted for classroom use by Robyn Adams and Jane McKenzie. Retrieved on May 14, 2019 from https:/ / classic.csunplugged.org/

Bocconi, S., Chioccariello, A., Dettori, G., Ferrari, A., \& Engelhardt, K. (2016). Developing computational thinking in compulsory education-implications for policy and practice. Seville: Join Research Center (European Commission). Retrieved on October 21, 2019 from http://publications.jrc.ec.europa.eu/ repository/bitstream/JRC104188/jrc104188_comp uthinkreport.pdf

Boucinha, R., Barone, D., Reichert, J., Brackmann, C., \& Schneider, A. (2019). Relationship between the Learning of Computational thinking and the Development of Reasoning. International Journal of Advanced Engineering Research and Science, 6(6), 623631. https:/ / doi.org/10.22161/ijaers.6.6.71
Brackmann, C. P., Barone, D. A. C., Boucinha, R. M., \& Reichert, J. (2019). Development of Computational Thinking in Brazilian Schools with Social and Economic Vulnerability: How to Teach Computer Science Without Machines. International Journal for Innovation Education and Research, 7(4), 79-96. https://doi.org/10.31686/ijier.Vol7.Iss4.1390

BRASIL. (2018). Ministério da Educação. Base Nacional Comum Curricular. Retrieved on March 29, 2019 from http:/ / basenacionalcomum.mec.gov.br/

CODE.ORG. (2015). Instructor Handbook - Code Studio Lesson Plans for Courses One, Two, and Three. Retrieved on February 5, 2019, from https:/ / code. org/curriculum/docs/k-5/complete.pdf

Curzon, P., Cutts, Q. I. , \& Bell, T. (2009) Enthusing and inspiring with reusable kinesthetic activities. In: ITiCSE '09 Proceedings of the 14th Annual ACM SIGCSE Conference on Innovation and Technology in Computer Science Education, Paris, France, 3(7), 9498. https:/ / doi.org/10.1145/1595496.1562911

Curzon, P., Mcowan, P. W., Plant, N., \& Meagher, L. R. (2014). Introducing teachers to computational thinking using unplugged storytelling, ACM Press, 89-92. https:/ / doi.org/10.1145/2670757.2670767

Guzdial, M. (2008). Education: Education: Paving the way for computational thinking. Communications of the ACM, 51(8), 25-27. https://doi.org/10.1145/ 1378704.1378713

Haseski, H. I., Ilic, U., \& Tugtekin, U. (2018). Defining a New 21st Century Skill-Computational Thinking: Concepts and Trends. International Education Studies, 11(4), 29-42. https://doi.org/10.5539/ ies.v11n4p29

Holmes, K., Prieto-Rodriguez, E., Hickmott, D., \& Berger, N. (2018). Using coding to teach mathematics: results of a pilot project. Integrated Education for the Real World: 5Th International Stem in Education Conference: Post-Conference Proceedings, Queensland University of Technology, Brisbane, Australia, 152-158. Retrieved on December 5, 2019 from https://stem-in-ed2018.com.au/wp-content / uploads/2019/02/5th-International-STEM-in-Ed ucation-Post-Conference-Proceedings-2018.pdf

Ingram, N., Holmes, M., Linsell, C., Livy, S., McCormick, M., \& Sullivan, P. (2019). Exploring an innovative approach to teaching mathematics through the use of challenging tasks: A New Zealand perspective. Mathematics Education Research Journal, 1-26. https:/ / doi.org/10.1007/s13394-019-00266-1

ISTE/ CSTA. (2011). Computational Thinking Teacher Resource. 2 ed. Retrieved on July 29, 2019 from www.iste.org/docs/ct-documents/ct-teacherresources_2ed-pdf.pdf?sfvrsn=2

Kalelioglu, F., Gülbahar, Y., \& Kukul, V. (2016). A framework for computational thinking based on a 
systematic research review. Baltic Journal of Modern Computing, 4(3), 583-596.

Kong, S. C., \& Abelson, H. (Editors). (2019). Computational Thinking Education. Springer Open: Singapore. https://doi.org/10.1007/978-981-136528-7

Leikin, R., Levav-Vineberg, A., Gurevich, I., \& Mednikov, L. (2006). Implementation of multiple solution connecting tasks: Do students' attitudes support teachers' reluctance? FOCUS on Learning Problems in Mathematics, 28, 1-22.

Liukas, L. (2015). Hello Ruby: adventures in coding. United States of America: Feiwel \& Friends.

Mailizar, M., \& Fan, L. (2020). Indonesian Teachers' Knowledge of ICT and the Use of ICT in Secondary Mathematics Teaching. Eurasia Journal of Mathematics, Science and Technology Education, 16(1), em1799. https:/ / doi.org/10.29333/ejmste/110352

Matos Filho, M. A. S., Da Silva, J. E. M. R., \& Queiroz, S. M. (2008). O Uso do Computador no Ensino de Matemática: implicações nas Teorias Pedagógicas a Infraestrutura Escolar. EDUCERE: Comunicação $e$ Tecnologia. Retrieved on September 11, 2019 from https://educere.pucpr.br/p19/anais.html

Molina, R. K., \& Schlemmer, E. (2011). O uso das tecnologias de informação e comunicação (TIC) em contextos escolares e a melhoria da qualidade da educação. Práxis Educacional, Ponta Grossa, 6(1), 91100. https:/ / doi.org/10.5212/PraxEduc.v.6i1.0009

Nacarato, A. M., Mengali, B. L. S., \& Passos, C. L. B. (2011). A Matemática nos anos iniciais do Ensino Fundamental: tecendo fios do ensinar e do aprender. Belo Horizonte: Autêntica.

Nascimento, S. P. (2015). As TIC na formação continuada de professores: desafios para os núcleos de tecnologia educacional no Estado de Goiás. 134 f. (Master's Dissertation in Education), Centro Universitário de Anápolis - UniEvangélica, Anápolis, Goiás, Brasil.

Oliveira, G. S. (2009). Crenças de professores dos primeiros anos do Ensino Fundamental sobre a prática pedagógica em Matemática. 206 f. (Tese de Doutorado em Educação), Faculdade de Educação, Universidade Federal de Uberlândia, Uberlândia, MG, Brasil.

Oliveira, G. S., \& Baraúna, S. M. (2012). Reflexões sobre a prática pedagógica de Matemática no Ensino Médio. In R. V. Puentes, O. F. Aquino, \& A. M. Longarezi (Org.) Ensino Médio, processos, sujeitos e docência. Uberlândia: EDUFU, Minas Gerais, Brasil, 267-289.

Pasqual Júnior, P. A., \& De Oliveira, S. (2019). Pensamento Computacional: Uma Proposta de Oficina para a Formação de Professores. Novas Tecnologias na Educação, 17(1), 62-71. https:/ / doi.org/10.22456/1679-1916.95707
Papert, S., \& Solomon, C. (1971). Twenty things to do with a Computer. Educational Technology Magazine. Artificial Intelligence Memo Number 248, 1-41.

Papert, S. (1980). Mindstorms: Children, Computers, and Powerful Ideas. Basic Books, A Division of Harper Collins Publishers, Inc.

Papert, S. (1993). Children's Machine: Rethinking School in the Age of the Computer. Basic Books, A Division of Harper Collins Publishers, Inc.

Peralta, H., \& Costa, F. (2007). Competência e confiança dos professores no uso das TIC. Sintese de um estudo internacional (on-line version). Sísifo. Revista de Ciências da Educação, 3, p.77-86. Retrieved on December 5, 2019 from http:/ / hdl.handle.net/10451/7028

Piaget, J. (1976). The Grasp of Consciousness: Action and Concept in the Youg Child. Cambridge, Mass: Harvard University.

Prado, M. E. B. B., \& Martins, M. C. (2001). A mediação pedagógica em propostas de formação continuada de professores em informática na educação. In: Congresso Internacional de Educação a Distância, ABED, Brasília, Brasil. Retrieved on June 9, 2019 from http:/ / www2.abed.org.br/visualizaDocume nto.asp?Documento_ID $=12$

Prieto-Rodriguez, E., \& Berretta, R. (2014). Digital Technology Teachers' Perceptions of Computer Science: It is not all about programming. IEEE Frontiers in Education Conference Proceedings, (Madrid 22-25 October, 2014), 897-901. https:// doi.org/10.1109/FIE.2014.7044134

Rocha, A. K. D. O., \& Prado, M. E. B. B. (2014). Uma abordagem tecnológica na formação do professor de Matemática. Revista Tecnologias na Educação, 6(11), 1-8.

Royal Society. (2012). Shut down or restart? The way forward for computing in UK schools. Royal Society. Retrieved on December 8, 2019 from https:/ / royalsociety.org/-/media/education/ computing-in-schools/2012-01-12-computing-inschools.pdf

Russo, J., Bobis, J., Downton, A., Hughes, S., Livy, S., McCormick, M., \& Sullivan, P. (2019). Teaching with challenging tasks in the first years of school: What are the obstacles and how can teachers overcome them? Australian Primary Mathematics Classroom, 24(1), 11-18

Sadovysky, P. (2007). Ensino de Matemática hoje: Enfoque, sentido e desafios. São Paulo: Ática.

Saito, F. S., \& Ribeiro, P. N. S. (2013). (Multi)letramento(s) digital(is) e teoria do posicionamento: análise das práticas discursivas de professores que se relacionam com as tecnologias da informação e comunicação no ensino público. 
RBLA, Belo Horizonte, 13(1), 37-65. https:/ / doi.org/ 10.1590/S1984-63982012005000017

Shadish, W. R., Cook, T. D., \& Campbell, D. T. (2001). Experimental and Quasi-Experimental Designs for Generalized Causal Inference (2nd Edition), Boston, Cengage Learning.

Sociedade Brasileira de Computação. (2017). Referenciais de Formação em Computação: Educação Básica. Retrieved on December 5, 2019 from http://www.sbc.org.br/educacao/diretrizespara-ensino-de-computacao-na-educacao-basica

Valente, J. A. (2016). Integração do pensamento computacional no currículo da educação básica: diferentes estratégias usadas e questões de formação de professores e avaliação do aluno. Revista e-Curriculum, 14(3), 864-897.

Valente, J. A. (2019). Pensamento Computacional, Letramento Computacional ou Competência Digital? Novos desafios da educação. Revista Educação e Cultura Contemporânea, 16(43), 147-168. https://doi.org/10.5935/2238-1279.20190008

Vieira, M. F. (2015), Efetivação do uso de Tecnologias na Educação: Desafios na formação de recursos humanos. In XXXV Congresso da Sociedade Brasileira de Computação (CSBC 2015 - DesafIE 2015), Universidade Federal de Pernambuco (UFPE).

Yadav, A., Zhou, N., Mayfield, C., Hambrusch, S., \& Korb, J. T. (2011). Introducing Computational Thinking in Education Courses. SIGCSE 11, March 9-12, Dallas, Texas, USA. https:/ / doi.org/10.1145/ 1953163.1953297

Wing, J. M. (2006). Computational thinking. Communications of the ACM, 49(3), 33-35. https:// doi.org/10.1145/1118178.1118215

Wing, J. M. (2014). Social Issues in Computing. https://doi.org/10.1109/MC.2014.179

Yadav, A., Mayfield, C., Zhou, N., Hambrusch, S., \& Korb, J. T. (2014). Computational thinking in elementary and secondary teacher education. $A C M$ Trans. Comput. Educ. 14(1), Article 5 (March 2014), 16 pages. https:/ / doi.org/10.1145/2576872

Yadav, A., Stephenson, C., \& Hong. H. (2017). Computational Thinking for Teacher Education. Communications of the ACM., 60(4), 56-62. https://doi.org/10.1145/2994591

\section{http://www.ejmste.com}

